\title{
Komitmen Organisasi dan Karakteristik Pekerjaan Terhadap Kepuasan Kerja Perawat
}

\author{
Ni Luh Septin Karmila Devi ${ }^{1}$, Rindu ${ }^{2}$ \\ 1,2Program Sarjana Kesehatan Masyarakat, Sekolah Tinggi I Imu Kesehatan Indonesia Maju \\ J. Harapan Nomor 50, Lenteng Agung - Jakarta Selatan 12610, Telp: (021) 78894045 \\ Email: ${ }^{1}$ septinkarmiladevi@gmail.com, ${ }^{2}$ rindualghie@gmail.com
}

\begin{abstract}
Abstrak
Kepuasaan kerja (job satisfaction) adalah keadaan emosional yang menyenangkan atau tidak menyenangkan dimana para karyawan memandang pekerjaannya. Kepuasaan kerja mencerminkan perasaan seseorang terhadap pekerjaannyaHal ini nampak pada pada sikap positif karyawan terhadap pekerjaan dan segala sesuatu yang dihadapi dilingkungan kerjanya. Penelitian ini bertujuan untuk mengetahui Hubungan Komitmen Organisasi dan Karakteristik pekerjaan Dengan kepuasan Kerja Perawat di Rumah Sakit Grha Permata lbu Depok Tahun 2016. Pada Penelitian ini, variabel independen I adalah Komitmen Organisasi sedangkan Variabel Independen 2 adalah Karakteristik Pekerjaan. Penelitian ini menggunakan pendekatan deskriptif kuantitatif cross sectional serta analisis Chi Square dengan Populasi I 45 dan menggunakan teknik quota sampling dengan sampel sebanyak 72 perawat. Alat pengumpulan data menggunakan kuesioner. Teknik analisis univariat dan bivariat, menggunakan program komputer. Berdasarkan analisis univariat terdapat 44,4\% responden menyatakan tingkat Komitmen Organisasi kurang baik, terdapat 30,6\% responden terdapat tingkat Karakteristik pekerjaan kurang baik dan terdapat 34,7\% responden terdapat tingkat kepuasan kerja kurang puas. Hasil analisis bivariat menunjukkan tidak ada hubungan antara komitmen organisasi (P-value $=0,213$ ) dengan kepuasan kerja dan ada hubungan antara karakteristik pekerjaan ( $P$-value $=0,007)$ dengan kepuasan kerja. Diharapkan RS. Grha Permata lbu melibatkan perawat dalam setiap kegiatan, baik kegiatan di dalam maupun di luar agar perawat merasa bahwa perusahaan tersebut adalah perusahaan yang terbaik untuk tempatnya bekerja.
\end{abstract}

Kata kunci : Karakteristik Pekerjaan, Kepuasan Kerja, Komitmen Organisasi

\begin{abstract}
Job satisfaction is an emotional state that is pleasant or unpleasant how employees view the work. Job satisfaction reflects a person's feelings toward their work, it looks at the positive attitude of employees towards work and everything that is faced in their work environment. This study aims to determine the characteristics of Relation Organizational Commitment and job satisfaction of nurse at Grha Permata lbu Hospital Depok 2016. In this study, the first independent variable is the Organizational Commitment while the second Independent Variable is the Job Characteristics. This study uses a quantitative descriptive cross sectional approach and analysis of Chi Square. Subjects of this study were 72 nurses. Tool data collection using questionnaires. Univariate and bivariate analysis techniques, using a computer program. Based on univariate analysis, contained $44.4 \%$ of respondents said the level of Organizational Commitment were unfavorable. There are $30.6 \%$ of respondents to rate Nurse's job characteristics were unfavorable and there were $34.7 \%$ of respondents are not satisfied the level of job satisfaction. The results of the bivariate analysis using Chi Square on variable organizational commitment to job satisfaction was obtained $p$ value $=0.213$, while the variable of job characteristics and job satisfaction obtained $p$ value $=0.007$. Is it required for Grha Permata lbu Hospital to involving all of the medical labor in all activities inside and outside so that they might feel that company hospital where they work is the best place fpr them to work.

Keywords : Job Characteristics, Job Satisfaction, Organozational Commitment.
\end{abstract}




\section{Pendahuluan}

Manajemen sumber daya manusia merupakan suatu perencanaan, pengorganisasian, pelaksanaan, dan pengawasan terhadap pengadaan, pengembangan, pemberian bala jasa, pengintegrasian, pemeliharaan dan pemisahan tenaga kerja dalam rangka mencapai tujuan organisasi. ${ }^{1}$

Kepuasaan kerja (job satisfaction) adalah keadaan emosional yang menyenangkan atau tidak menyenangkan dimana para karyawan memandang pekerjaannya. Kepuasaan kerja mencerminkan perasaan seseorang terhadap pekerjaannya. Hal ini nampak pada pada sikap positif karyawan terhadap pekerjaan dan segala sesuatu yang dihadapi dilingkungan kerjanya. Departemen sumber daya manusia atau manajemen harus selalu memonitor kepuasaan kerja karena hal ini mempengaruhi sikap absensi, perputaran tenaga kerja, kepuasaan kerja dan masalah-masalah penting lainnya. ${ }^{2}$

Kepuasan kerja di Rumah Sakit yang rendah menimbulkan ketidakpuasan kerja. Dampak buruk dari ketidakpuasan kerja akan sangat merugikan perusahaan. Karyawan akan melakukan hal-hal yang tidak sepantasnya dilakukan seperti: mogok kerja, ketidakhadiran karyawan, turunnya kinerja karyawan dan lainlain. Selain itu ketidakpuasan kerja berdampak pada loyalitas karyawan, turn over karyawan akan tinggi. Hal ini akan berdampak buruk kepada citra Rumah Sakit. $^{3}$

Pekerja dengan kepuasan yang tinggi mengalami perasaan positif ketika mereka berpikir tentang tugas dan mengambil bagian dalam aktivitas mereka. Sebaliknya, pekerja dengan kepuasan kerja rendah mengalami perasaan yang negatif terhadap hal yang sama. ${ }^{4}$

Komitmen organisasi didifinisikan sebagai dorongan dari dalam diri individu untuk berbuat sesuatu agar dapat menunjang keberhasilan organisasi sesuai dengan tujuan dan meletakkan kepentingan organisasi diatas kepentingan pribadinya, komitmen organisasi menunjukkan keyakinan dan dukungan yang kuat terhadap nilai dan sasaran (goal) yang ingin dicapai oleh organisasi. Komitmen organisasi bisa tumbuh disebabkan karena individu memiliki ikatan emosional terhadap organisasi yang meliputi dukungan moral dan menerima nilai yang ada didalam organisasi serta tekad dalam diri untuk mengabdi kepada organisasi. ${ }^{5}$

Selain komitmen organisasi, karakteristik pekerjaan juga mempengaruhi kepuasaan kerja seseorang karakteristik pekerjaan berkaitan dengan cara bagaimana karyawan menilai tugastugas dalam pekerjaannya. Mengembangkan model pendekatan karakteristik pekerjaan yang menunjukkan bahwa pekerjaan apapun dapat dideskripsikan dalam lima dimensi inti yaitu keanekaragaman keterampilan, identitas tugas, signifikasi tugas, otonomi serta umpan balik. Pengorganisasian yang baik perlu memperhatikan karakteristik pekerjaan dan komitmen organisasi demi tercapainya tujuan organisasi dengan efektif dan efisensi. ${ }^{6}$

Rumah sakit merupakan institusi pelayanan kesehatan yang menyelenggarakan pelayanan kesehatan perorangan secara paripurna yang menyediakan pelayanan rawat inap, rawat jalan, dan gawat darurat menurut Undang-undang nomor 14 tahun 2009 tentang rumah sakit pada pasal 1 ayat 1 . Rumah sakit dituntut untuk dapat memberikan pelayanan kesehatan yang terbaik nagi pasiennya secara khusus serta bagi masyarakat umum secara luas. Kualitas rumah sakit sangat ditenttukan oleh dua faktor utama yaitu pelayanan oleh petugas rumah sakit dan bangunan serta prasarana dari rumah sakit itu sendiri. Dampak yang dapat ditimbulkan ketika kedua faktor tesebut tidak terpenuhi dengan baik adalah buruknya pelayanan rumah sakit baik dalam keadaan normal maupun saat terjadi bencana. $^{7}$

Hasil penelitian mengenai hubungan antara komitmen organisasi dan iklim organisasi dengan kepuasan kerja karyawan menunjukkan ada hubungan yang positif dan sangat signifikan antara komitmen organisasi dengan kepuasan kerja karyawan. Hal ini menunjukkan bahwa semakin tinggi komitmen karyawan terhadap organisasi maka akan semakin tinggi pula kepuasan kerjanya. Dari hasil penelitian mengenai pengaruh karakteristik pekerjaan dan kepuasan kerja terhadap OCB (Organizational Citizenship Behavior) tahun 2012 diketahui bahwa karakteristik pekerjaan memiliki pengaruh yang signifikan terhadap kepuasan kerja akan memberikan nilai lebih pada pekerjaan tersebut, yang dapat menghasilkan karyawan akan lebih termotivasi dan merasa puas untuk menggunakan tenaga dan usahanya dalam bekerja, sehingga terbentuklah kepuasan kerja karyawan di dalam perusahaan. ${ }^{8,9}$

Dari hasil observasi pendahuluan peneliti di Rumah Sakit Grha Permata Ibu dibagian perawat rawat jalan sebanyak 30 orang diperoleh hasil 17 orang tidak memiliki kepuasan dalam bekerja , 13 orang memilki kepuasan dalam bekerja. Sehingga karyawan yang memiliki kepuasaan bekerja rendah terhadap pekerjaannya biasanya karena gaji yang tidak sesuai, pekerjaan yang terlalu banyak dan kurangnya reward terhadap hasil pekerjaannya. 
Komitmen organisasi dan karakteristik pekerjaan yang berkembang dalam institusi akan sangat berpengaruh secara keseluruhan. Kepuasan kerja akan mendorong untuk lebih bersemangat dalam bekerja dan mampu mendorong terbentuknya komitmen organisasi yang baik dalam instansi. Melihat pentingnya hubungan komitmen organisasi dan karakteristik pekerjaan terhadap kepuasan kerja di Rumah Sakit Grha Permata Ibu maka penulis dalam penelitian ini akan membahas mengenai "Hubungan antara Komitmen Organisasi dan Karakteristik Pekerjaan terhadap kepuasan Kerja Perawat di Rumah Sakit Grha Permata Ibu Depok Tahun 2016”

Tujuan umum dalam penelitian adalah Mengetahui hubungan antara komitmen organisasi dan karakteristik pekerjaan terhadap kepuasan kerja Perawat Rumah Sakit Grha Permata Ibu tahun 2016.

\section{Metode}

Penelitian ini merupakan penelitian kuantitatif, menggunakan desain penelitian cross sectional yaitu yaitu suatu penelitian dimana variabel independen dan variabel dependennya diteliti secara bersamaan dalam periode yang sama. Variabel independen dari penelitian ini adalah komitme organisasi dan karakteristik pekerjaan sedangkan variabel dependennya adalah kepuasan kerja perawat RS Grha Permata Ibu Depok Tahun 2016. ${ }^{10}$

Populasi adalah jumlah keseluruhan semua anggota yang mempunyai karakteristik tertentu sesuai dengan penelitian. Populasi dalam penelitian ini adalah perawat RS. Grha Permata Ibu Depok yang berjumlah 145 orang. $^{10}$

Sampel adalah sebagian atau wakil dari populasi yang diteliti. ${ }^{11}$ Adapun teknik pengambilan sampel dalam penelitian ini dengan menggunakan metode non Rendom Sampling yaitu pengambilan sampel yang tidak memberikan kesempatan yang sama. Penentuan jumlah sampel dihitung berdasarkan rumus besar sampel dengan menggunakan rumus (Lemeshow) sebagai berikut $:^{12}$

$$
\begin{aligned}
& \mathrm{n}=\frac{\mathrm{z}^{2} \mathrm{p}(1-\mathrm{p}) \mathrm{N}}{\mathrm{d}^{2}(\mathrm{~N}-1)+\mathrm{z}^{2} \mathrm{p}(1-\mathrm{p})} \\
& \mathrm{n}=\frac{1,96^{2} \cdot 0,5(1-0,5) 145}{\left.0,1^{2} 145-1\right)+1,96 \cdot 0,5(1-0,5)} \\
& \mathrm{n}=\frac{1,9208 \cdot 0,5 \cdot 145}{0,01 \cdot 144+0,98 \cdot 0,5} \\
& \mathrm{n}=\frac{139,258}{1,44+0,49}=\frac{139,258}{1,93} \\
& \mathrm{n}=72,15
\end{aligned}
$$

Jadi jumlah sampel dalam penelitian ini adalah sampel 72 sampel. Kriteria Inklusi dan Eksklusi adalah (1) Kriteria inklusi yaitu perawat Rawat inap Rumah Sakit Grha Permata Ibu, perawat rawat jalan Rumah Sakit Grha Permata Ibu. (2) Kriteria Eksklusi yaitu Pegawai Non medis Rumah Sakit Grha Permata Ibu, Seluruh Dokter Rumah Sakit Grha Permata Ibu, Perawat yang tidak hadir pada saat penelitian.

Sumber data yang digunakan dalam penelitian ini adalah (1) Data primer adalah data yang diperoleh secara langsung dari obyek yang diteliti, baik dari obyek individual (responden) maupun dari suatu instansi yang mengolah data untuk keperluan dirinya sendiri. Data diperoleh langsung dari tempat penelitian dengan cara melakukan wawancara dan menyebarkan kuesioner responden. (2) Data Sekunder adalah data yang diperoleh secara tidak langsung untuk mendapatkan informasi dari obyek yang diteliti, biasanya data tersebut diperoleh dari pihak kedua baik dari obyek secara individual (responden) maupun dari suatu badan (instansi) yang sengaja melakukan pengumpulan data dari instansiinstansi atau badan lainnya untuk keperluan penelitian. ${ }^{10}$

Cara pengumpulan data dengan (1) Wawancara, wawancara merupakan proses tanya jawab antara peneliti dengan responden untuk memperoleh keterangan secara lisan. Pada penelitian ini wawancara dilakukan untuk memperoleh data awal dalam penyusunan rumusan masalah penelitian. (2) Angket, Angket adalah suatu cara pengumpulan data atau suatu penelitian mengenai suatu masalah yang umumnya banyak nmenyangkut kepentingan umum (orang banyak). (3) Studi dokumen adalah kegiatan mengumpulkan informasi dengan mempelajari sumber data tertulis untuk memperoleh data sekunder mengenai profil Rumah Sakit Grha Permata Ibu serta komposisi karyawan pada bulan Mei 2106. (4) Studi Pustaka adalah kegiatan mengumpulkan data dengan cara mempelajari teori-teori yang berhubungan dengan pokok bahasan penelitian, baik yang berasal dari literatur maupun dari karangan ilmiah terdahulu. ${ }^{10}$

Analisi univariat dilakukan setiap variabel dari hasil penelitian.Pada umumnya analisis ini hanya menghasilkan distribusi frekuensi dan presentase dari tiap variabel.Analisis univariat bertujuan untuk mendeskripsikan masing-masing variabel penelitian. ${ }^{10}$

Analisa univariat mendeskripsikan karakteristik masing-masing variabel bebas (independent) maupun variabel terikat (dependen). Analisa variabel univariat dalam 
penelitian ini adalah variabel independen. Analisa bivariat digunakan untuk menganalisis hubungan antara komitmen organisasi dan karakteristik pekerjaan terhadap kepuasan kerja perawat RS. Grha Permata Ibu depok tahun 2016. Uji statistik menggunakan metode chi-Square dengan derajat kepercayaan yang digunakan adalah $95 \%=0.05$, dari uji tersebut dapat diketahui ada tidaknya hubungan antara independen dengan variabel dependen , dengan mengambil keputusan: (1) Bila Pvalue < 0.05, maka dikatakan (Ho) ditolak artinya kedua variabel secara statistik terdapat hubungan yang bermakna. (2) Bila Pvalue $>0.05$ maka dikatakan (Ho) gagal ditolak artinya kedua variabel secara statistik tidak terdapat hubungan yang bermakna. ${ }^{10}$

\section{Hasil}

Penyajian hasil penelitian disusun berdasarkan sistematika yang dimulai dengan gambaran analisis univariat yang bertujuan untuk melihat distribusi frekuensi variabel independen dan dependen.

Tabel 1. Karakteristik Responden Perawat RS. Grha Permata Ibu Depok Tahun 2016

\begin{tabular}{lcc}
\hline Variabel & Frekuensi & Persen \\
\hline Jenis Kelamin & & \\
$\quad$ Pria & 5 & 6,9 \\
$\quad$ Wanita & 67 & 93,1 \\
Usia & & \\
$\quad$ 20-30 Tahun & 52 & 72,2 \\
$\quad$ 30 Tahun & 20 & 27,8 \\
Lama Kerja & & \\
$\quad<1$ Tahun & 7 & 9,7 \\
$\quad>1$ Tahun & 65 & 90,3 \\
\hline
\end{tabular}

Berdasarkan hasil penelitian berdasarkan jenis kelamin diketahui bahwa paling banyak wanita sebanyak 67 orang atau sebesar 93,1\%. Responden paling sedikit pria berjumlah 5 orang atau sebesar 6,9\%. Usia perawat sebagian besar berusia 20 tahun sampai dengan 30 tahun sebanyak 52 orang sebesar $72,2 \%$, diikuti oleh responden berusia $>30$ tahun sebanyak 20 orang atau sebesar $27,8 \%$. Lama kerja paling banyak bekerja $>1$ tahun sebanyak 65 orang atau sebesar 9,7\%. Responden paling sedikit $<1$ tahun berjumlah 65 orang atau sebesar $90,3 \%$.

Tabel 2. Distribusi frekuensi responden berdasarkan aspek kepuasan kerja di RS Grha Permata Ibu

\begin{tabular}{lll}
\hline \multicolumn{1}{c}{ Variabel } & n & \% \\
\hline Komitmen Organisasi & & \\
Kurang Baik & 32 & 44,4 \\
Baik & 40 & 55,6
\end{tabular}

\begin{tabular}{lll}
$\begin{array}{l}\text { Karakteristik Pekerjaan } \\
\text { Kurang Baik }\end{array}$ & & \\
$\quad$ Baik & 50 & 30,6 \\
Kepuasan Kerja & & 69,4 \\
$\quad$ Kurang Puas & 25 & 34,7 \\
$\quad$ Puas & 47 & 65,3 \\
\hline
\end{tabular}

Dari hasil penelitian diketahui bahwa perawat yang komitmen organisasinya Kurang baik sebanyak 32 orang atau sebesar 44,4\% lebih sedikit dibandingkan komitmen organisasinya Baik sebanyak 40 orang atau sebesar 55,6\% perawat yang karakteristik pekerjaannya Kurang baik sebanyak 22 orang atau sebesar 30,6\% lebih sedikit dibandingkan karakteristik pekerjaannya Baik sebanyak 50 orang atau sebesar 69,4\%. Diketahui bahwa perawat yang kepuasan kerja kurang puas sebanyak 25 orang atau sebesar $34,7 \%$ lebih sedikit dibandingkan kepuasan kerja puas sebanyak 47 orang atau sebesar $65,3 \%$ di RS. Grha Permata Ibu.

Organisasinya Baik sebanyak 40 orang atau sebesar 55,6\% di RS. Grha Permata Ibu. Diketahui bahwa perawat yang karakteristik pekerjaannya Kurang baik sebanyak 22 orang atau sebesar 30,6\% lebih sedikit dibandingkan perawat yang karakteristik pekerjaannya Baik sebanyak 50 orang atau sebesar 69,4\%di RS. Grha Permata Ibu. Diketahui bahwa perawat yang kepuasan kerja kurang puas sebanyak 25 orang atau sebesar $34,7 \%$ lebih sedikit dibandingkan perawat yang kepuasan kerja puas sebanyak 47 orang atau sebesar 65,3\% di RS. Grha Permata Ibu.

Berdasarkan hasil analisis bivariat antara komitmen organisasi terhadap kepuasan kerja menunjukan bahwa tidak terdapat beda proporsi kepuasan kerja yang signifikan antara kelompok perawat yang memiliki komitmen organisasi kurang baik dan kelompok perawat yang memiliki komitmen organisasi baik $(P$-value $=0,213)$. 
Tabel 3. Hubungan Komitmen organisasi, karakteristik pekerjaan terhadap kepuasan kerja di RS Grha Permata Ibu Depok Tahun 2016

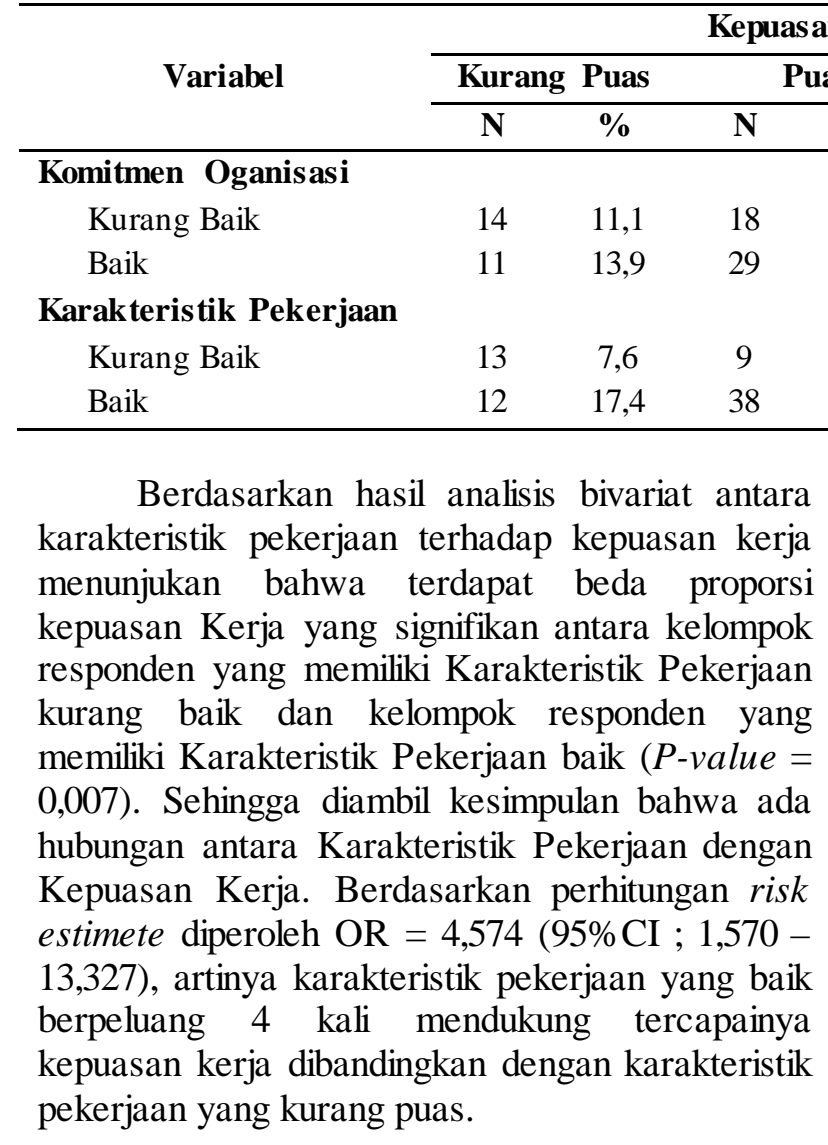

\section{Pembahasan \\ Hubungan Komitmen Organisasi Terhadap Kepuas an Kerja}

Hasil penelitian hubungan antara komitmen organisasi dengan kepuasan kerja diperoleh $\mathrm{P}$ value $\geq 0,05$ yakni sebesar 0,213. Hal ini memperlihatkan bahwa komitmen organisasi tidak memiliki hubungan yang signifikan terhadap kepuasan kerja. Berdasarkan uji Chi Square antara Komitmen Organisasi perawat RS Grha Permata Ibu Depok tidak memiliki hubungan yang signifikan terhadap Kepuasan Kerja sehingga $\mathrm{H}(1)$ ditolak.

Komitmen organisasi mengacu pada keadaan psikologis yang mengikat individu untuk organisasi Sebaliknya untuk kepuasan kerja yang terkait dengan pekerjaan. komitmen organisasi yang bersangkutan dengan perasaan keterikatan dengan tujuan dan nilai-nilai organisasi. Mengukur Komitmen organisasi adalah penilaian kesesuaian antara nilai-nilai individu sendiri dan keyakinan dan orang-orang dari organisasi. ${ }^{13}$

Terdapat temuan yang meneliti pengaruh profesionalisme dan komitmen organisasi terhadap kepuasan kerja menunjukkan bahwa
P-value $\quad$ OR

$\begin{array}{llll}20,9 & 32 & 32,0 & 0,213 \\ 26,1 & 40 & 40,0 & \end{array}$

$\begin{array}{llll}14,4 & 22 & 22,0 & 0,007\end{array}$

4,574

$32,6 \quad 50 \quad 50,0 \quad(1,570-13,327)$

tidak ada pengaruh antara komitmen organisasi terhadap kepuasan kerja $(p=0.068)$. Namun tidak sejalan dengan Hasil penelitian ini bahwa ada hubungan yang positif dan sangat signifikan antara komitmen organisasi dengan kepuasan kerja karyawan. Hal ini menunjukkan bahwa semakin tinggi komitmen karyawan terhadap organisasi maka akan semakin tinggi pula kepuasan kerjanya. tentang hubungan antara komitmen terhadap organisasi, keterlibatan terhadap kerja dan kepuasan kerja, menunjukkan bahwa terdapat hubungan yang positif antara komitmen terhadap organisasi dengan kepuasan kerja. Faktor Kontinuans dan faktor Normatif berpengaruh secara signifikan terhadap kepuasan kerja. Ini menunjukkan bahwa komitmen organisasi pada diri karyawan Universitas Muham-madiyah Surakarta dalam mempengaruhi kepuasan kerjanya, sangat ditentukan adanya pertimbangan dan keputusan untuk menetap dalam organisasi sebagai bagian pemenuhan kebutuhan dan adanya keyakinan bahwa berkarya pada organisasi merupakan kewajiban moral yang tidak boleh ditinggalkan.,

Menurut peneliti yang dapat dilakukan untuk meningkatkan kepuasan kerja berdasarkan komitmen organisasi adalah dengan mengidentifikasi faktor-faktor yang mempengaruhi tingkat komitmen organisasi perawat meliputi: Perasaan, Sikap dan perilaku Setelah menggali faktor yang paling berpengaruh terhadap kepuasan kerja maka dapat dilakukan serangkaian upaya perbaikan yang tepat sasaran. Dengan tercapainya tingkat komitmen organisasi yang tinggi diharapkan.

\section{Hubungan Karakteristik Pekerjaan Terhadap Kepuasan Kerja}

Hasil penelitian hubungan antara Karakteristik Pekerjaan terhadap kepuasan kerja diperoleh $\mathrm{P}$ value $\leq 0,05$ yakni sebesar 0,007 . Hal ini memperlihatkan bahwa Karakteristik Pekerjaan memiliki hubungan yang signifikan terhadap kepuasan kerja. Nilai odd ratio sebesar 
4,574 artinya perawat yang memiliki Karakteristik Pekerjaan yang tinggi mempunyai peluang 4 kali memiliki kepuasan kerja.Berdasarkan uji Chi Square antara Karakteristik Pekerjaan perawat RS Grha Permata Ibu Depok memiliki hubungan yang signifikan terhadap Kepuasan Kerja sehingga H(2) diterima.

Karakteristik pekerjaan merupakan suatu perancangan kegiatan kerja karyawan yang disusun berdasarkan keinginan dan kemampuan karyawan tersebut, karyawan bekerja tidak hanya untuk dapat memenuhi kebutuhan lainnya, juga bertujuan untuk menambah kepuasan kerja dengan pekerjaan yang tepat, dan mengetahui kinerjanya dari umpan balik dari perusahaan, sebagai hasil yang diberikannya kepada perusahaan. ${ }^{9}$

Terdapat temuan hasil Penelitian yang sama yaitu meneliti tentang Pengaruh Karakteristik Individu, Karakteristik Pekerjaan, Iklim Organisasi Terhadap Kepuasan dan Kinerja Karyawan. Karakteristik pekerjaan dari karyawan PTP, memberikan pengaruh terbesar terhadap kepuasan karyawan, namun demikian dari besaran pengaruh tersebut, menandakan bahwa karakteristik karyawan PTPN tersebut selama ini belum optimal. Sebagaimana kita ketahui bahwa lengkap, terinci dan berkualitasnya karakteristik pekerjaan pada era persaingan yang sangat ketat pada saat sekarang ini merupakan faktor pendukung yang menentukan tingkat kepuasan karyawan yang pada ahirnya akan meningkatkan kelangsungan dan keberhasilan suatu perusahaan. Baiknya karakteristik pekerjaan merupakan suatu keharusan dalam meningkatkan kepuasan pekerjaan. Temuan penelitian yang sama yaitu meneliti tentang Pengaruh Karakteristik Pekerjaan, Karakteristik Organisasi, dan Karakteristik Individu Terhadap Kepuasan Kerja Karyawan Bank Swasta Di Provinsi Sulawesi Selatan. Ini menjelaskanbahwa variabel karakteristik pekerjaanmemiliki pengaruh linear danpositif (searah) yang signifikan terhadap kepuasan kerja karyawan bank swasta diPropinsi Sulawesi Selatan. Koefisienregresi tersebut menunjukan bahwa semakin tinggi karakterisitk pekerjaanyang dilakukan, maka kepuasan kerja karyawan juga akan cenderung semakintinggi; demikian pula sebaliknya, dengan asumsi faktorfaktor lain yang mempengaruhi kepuasan kerja

\section{Saran}

Karakteristik pekerjaan berpengaruh positif dan signifikan, semakin tinggi tingkat karakteristik pekerjaan maka semakin tinggi pula kepuasan kerja Sebaliknya, ketika tingkat karakteristik pekerjaan menurun, maka juga dapat menurunkan tingkat kepuasan kerja. karyawan dianggap konstan.Implikasi dari hasil penelitian bahwa karakteristik pekerjaan sangat baik digunakan sebagai peramal kepuasankerja karyawan. Oleh karena itu, karakteristik pekerjaan penting dipertimbangkan dalam menetapkan kebijakan peningkatan kepuasan kerja karyawan. ${ }^{15,16}$

Menurut peneliti yang dapat dilakukan untuk meningkatkan kepuasan kerja berdasarkan Karakteristik Pekerjaan adalah dengan mengidentifikasi yang mempengaruhi tingkat Karakteristik pekerjaan seperti perancangan kegiatan kerja karyawan yang disusun berdasarkan keinginan dan kemampuan karyawan tersebut, karyawan bekerja tidak hanya untuk dapat memenuhi kebutuhan lainnya, juga bertujuan untuk menambah kepuasan kerja dengan pekerjaan yang tepat, dan mengetahui kinerjanya dari umpan balik dari perusahaan, sebagai hasil yang diberikannya kepada perusahaan. Dengan tercapainya tingkat Karakteristik Pekerjaan yang tinggi diharapkan dapat meningkatkan kepuasan kerja perawat di Rumah Sakit Grha Permata Ibu Depok.

\section{Kesimpulan}

Berdasarkan hasil analisis dan pembahasan yang telah dikemukakan oleh peneliti ini dapat diperoleh kesimpulan Komitmen Organisasi tidak memiliki hubungan yang signifikan dengan Kepuasan Kerja, P-value $=0.213$. Menurut peneliti hal ini maka dapat dilakukan serangkaian upaya perbaikan yang tepat sasaran. Dengan tercapainya tingkat komitmen organisasi yang tinggi diharapkan dapat meningkatkan kepuasan kerja perawat

Karakteristik Pekerjaan memiliki hubungan yang signifikan dengan kepuasan kerja, P-value = 0.007 dengan bekerja tidak hanya untuk dapat memenuhi kebutuhan lainnya, juga bertujuan untuk menambah kepuasan kerja dengan pekerjaan yang tepat, dan mengetahui kinerjanya dari umpan balik dari perusahaan, sebagai hasil yang diberikannya kepada perusahaan. Dengan tercapainya tingkat Karakteristik Pekerjaan yang tinggi diharapkan dapat meningkatkan kepuasan kerja perawat.

Rumah sakit perlu menata kembali karakteristik pekerjaan yang baik, sehingga dapat menumbuhkan nilai bagi karyawan tersebut yang berdampak langsung dan memberikan kenyamanan kepada perawat untuk melakukan suatu pekerjaan dengan keterampilan yang dimiliki, dan juga bisa dilibatkan dalam 
pembuatan jadwal pekerjaan sehingga ada kontribusi yang berarti bagi organisasi. Sehingga dari hasil pekerjaan itu adanya informasi yang jelas mengenai seberapa baik pekerjaan itu dilakukan dan juga lebih sering melibatkan karyawan dalam setiap kegiatan, baik kegiatan di dalam maupun di luar agar perawat merasa bahwa perusahaan tersebut adalah perusahaan yang terbaik untuk tempatnya bekerja, serta memacu motivasi karyawan agar dapat bekerja lebih baik lagi serta meningkatkan komitmen setiap karyawan terhadap perusahaan.

\section{Daftar Pustaka}

1. Mangkunegara AP. Manajemen Sumber Daya Manusia Perusahaan. Bandung: Remaja Rosdakarya; 2015.

2. Danang S. Manajemen dan pengembangan Sumber Daya Manusia. Yogyakarta: CAPS (Center For Academic Publishing Service); 2015.

3. Gumilar EA. Pengaruh Faktor-faktor Kepuasan Kerja Terhadap Kinerja Karyawan. Skripsi Fakultas Psikologi Universitas Islam Negeri Syarif Hidayatullah: Jakarta; 2010.

4. Wibowo. Perilaku Salam Organisasi. Jakarta: Rajagrafindo Persada; 2015.

5. Kartika A. Pengaruh Komitmen Organisasi dan Ketidakpastian Lingkungan Dalam Hubungan Antara Partisipasi Anggaran dengan Senjangan Anggaran. Jurnal Program Studi Akuntansi Universitas Stikubank; 2010.

6. Djastuti I. Pengaruh Karakteristik Pekerjaan Terhadap Komitmen Organisasi Karyawan Tingkat Managerial Perusahaan Jasa Konstruksi Dalam Menghadapi Bencana_Konstruksi. Jawa Tengah: Jurnal Universitas Diponegoro;2011.

7. Sanjaya M, Ulfa M. Evaluasi Sarana dan Prasarana RS dalam Menghadapi Bencana Kebakaran: Yogyakarta. 2014
8. Yudhi S. Hubungan antara Komitmen Organisasi dan Iklim Organisasi Dengan Kepuasan Kerja Karyawan Universitas Muhammadiyah Surakarta: Jurnal Fakultas Psikologi Universitas Muhammadiyah Surakarta; 2012.

9. Otmo FJ. Pengaruh Karakteristik Pekerjaan Dan Kepuasan Kerja Terhadap OCB (Organizational Citizenship Behavior) Pada Karyawan PT. Menara Agung. Padang: Jurnal Fakultas Ekonomi Universitas Negeri Padang; 2012.

10. Notoadmojo S. Metodologi Penelitian Kesehatan. Jakarta: Rineka Cipta; 2012.

11. Notoadmojo S. Pengembangan Sumber Daya manusia. Jakarta: Rineka Cipta; 2010.

12. Lemeshow S. \& David W.H.Jr. Besar Sampel dalam Penelitian Kesehatan. Gadjahmada University Press: Yogyakarta; 1997.

13. Salleh R, Nair SM, Harun H. Job Satisfaction, Organizational Commitment and Turnover Intention: A Case Study on Employees Of a Retail Company in Malaysi; 2012.

14. Rahmi BM. Pengaruh Kepemimpinan Transformasional Terhadap Organizational Citizenship Behavior dan Komitmen Organisasional dengan Mediasi Kepuasan Kerja SMA Negeri di kabupaten Lombok Timur: Jurnal Fakultas Ekonomi Universitas Udayana Bali; 2013.

15. Lubis Y. Pengaruh Karakteristik Individu, Karakteristik Pekerjaan iklim Organisasi terhadap Kepuasan dan Kinerja Karyawan. Sumatera Utara: Jurnal Fakultas Pascasarjana Universitas Pasundan; 2012.

16. Akbar A. Pengaruh Karakteristik Pekerjaan, Karakteristik Organisasi, dan Karakteristik Individu Terhadap Kepuasan Kerja Karyawan Bank Swasta. Sulawesi Selatan: Jurnal Fakultas Ekonomi Universitas Hasanuddin; 2009. 